\title{
A Study of Adjustment of Students At +2 Stages in Relation to their Academic Achievement
}

\author{
Dr. Dipti Choudhury ${ }^{1 *}$
}

\section{ABSTRACT}

The present study examined the adjustment level of students in relation to their academic achievement. The study was made on 400 students of +2 stage, studying in different degree colleges of Kamrup District of Assam. The sample for study was selected by using stratified random sampling procedure. The tools used in the present investigation were-(i) Tool for academic achievement and (ii) Standardized test. The mean score and S.D. were calculated. The study indicated that students belongs to the category of 'academic consistency' are better adjusted than the students belongs to the category of 'academic fluctuation' and students under the category of 'academic deterioration' are less adjusted than the students of 'academic improvement' category.

Keywords: Adjustment, Academic achievement, Achievement level, +2 Stages

Adjustment is a continuous and life-long process and life means continuous adjustment to changes in the physical and social environment. Throughout the life individual faces situations in which prompt and complete satisfaction of his need is not possible. All these situations call for adjustment.

Adjustment is a process by means of which an individual seems to maintain physiological and psychological equilibrium and propels himself towards self-enhancement and represents the quality of an individual's behavior in relation to his interpersonal relationship. Symonds (1946) defined adjustment "as a satisfactory relation of an organism to environment". The word satisfactory relation may mean adaptation to the demand of reality. Thus adjustment is a process that helps a person to lead a happy and contented life while maintaining a balance between his needs and his capacity to fulfill them. In addition to his own basics needs, an individual is also subjected to certain demands of society. If he thinks only in terms of satisfying his own needs without thought of the norms, ethics and cultural tradition of society, he will not be adjusted to his environment. Adjustment does not cater only to one's own demands but also to the demands of society. Also adjustment involves gratification of a person's need as governed by the demands of various environ mental situations. This is not however a one-day process. An individual

\footnotetext{
${ }^{1}$ Associate Professor, Department of Education, M.N.C Balika Mahavidyalaya, Nalbari, Assam *Corresponding Author

(C) 2015 I D Choudhury; licensee IJIP. This is an Open Access Research distributed under the terms of the Creative Commons Attribution License (http://creativecommons.org/licenses/by/2.0), which permits unrestricted use, distribution, and reproduction in any Medium, provided the original work is properly cited.
} 
maintains the balance between himself and his surroundings either by modifying his own behavior or by modifying the environment. In other words, adjustment is an all- inclusive term meaning relationship between an individual and his environment through which his needs are satisfied in accordance with social demands. It includes traits of behavior and motives for behavior as well as adjustment made with these traits and motives.

Adjustment from the point of view of psychology can be defined as a process of need reduction. Every living organism develops his own needs and this must be satisfied by interaction with the environment. But there are so many hindrances to come across in the process of need satisfaction. Unfulfilled needs always create frustration, dissatisfaction or the problem of adjustment. The problem of adjustment of an individual plays an important role in his total development .Particularly, at the stage of adolescence when the students are at the high school or at college, the adjustment problem can have adverse effect upon them .Most students as a person have problems. Many of these problems occurs as a result of natural growth process from late boyhood to adolescence or adolescence to early adulthood and they necessitate adjustment. At this stage they also experience a number of inner and outer stresses. The student has to adjust himself to the problem of home, social living, emotional needs and health. These are general problem that confronts all adolescents .In addition to these, the students has problems peculiar to his academic environment and its demands. Every student must adjust himself to the problems arising out of his career. The school or college represents an enlarged sphere of self-directed activity and of self-dependence the demands upon the students are much greater during college life than his earlier school life because of lessened direction by instructors. Thus a student's success depends on understanding how to develop his capacities and putting them to maximum use. The adjustment to the environment promotes his efficient functioning but he may not be able to adjust himself normally owing to certain factors.A significantly large number of students has poor adjustment which interferes with their academic work and often leads to poor achievement and even to failure.

Several research studies attributed a strong association between adjustment and academic achievement. Centi (1962) conducted a study on personality factors of college success. A definite relationship was found to be existing between levels of achievement and related adjustment factor in this study. Chawla (1970) carried out a study on 'Adjustment and Academic Achievement' by using Rotter's Incomplete Sentences Blank (ISB). The study clearly indicates that academic achievement is closely related to the adjustment .In their study, Patel and Joshi(1974) concluded that the high achiever in terms of family adjustment are more adjusted than low achievers, girls are better-adjusted than boys. Similar trend was found in personal adjustment and social adjustment. According to Sharma (1983) students with better and poor adjustment do not differ significantly in their academic achievement. This study revealed that level of adjustment and academic progress are not related to each other. Ahluwalia and Kalia(1986) carried out the study on the adjustment differences among high achieving and low achieving adolescents and summarized that high achievers have less adjustment problems on 
emotional and educational areas in comparison to low achievers. Panda (1997) carried out his study to find out the independent contribution of adjustment on academic achievement of high school boys and girls. He reported that adjustment is an essential factor for the progress of academic achievement of a student.

\section{OBJECTIVE}

1. To know the achievement level of higher secondary students.

2. To know the adjustment level of higher secondary students in relation to their academic progress.

\section{METHOD}

\section{Sample:}

A sample of 400 students of later-adolescence, i.e. age group $16^{+}$, studying at the higher secondary level was selected by using stratified random sampling procedure from different degree colleges of Kamrup district of Assam.

\section{Tools:}

Two types of tools were selected for the present study_

a) Standardized test (Adjustment Inventory for school student-A.K.P. Sinha and R.P. Singh)

b) Tool for academic achievement (Marks of examination)

\section{Data Collection:}

Before the commencement of the study, Heads of the institutions were requested to permit the investigator to collect data and to conduct the inventory on the subjects.

The examination marks which were taken as a measure of academic achievement of students were collected from the official records maintain in the respective institutions.

\section{ACHIEVEMENT LEVELS OF HIGHER SECONDARY STUDENTS}

In order to know the achievement levels of higher secondary students, the investigator first collected the total marks of their High School Leaving Certificate(HSLC) examination, ,Higher Secondary First year (HS $1^{\text {st }}$ Year) Examination and Higher Secondary School Leaving Certificate (HSSLC) examination from their respective institutions and analyzed. Then the students were grouped on the basis of marks obtained in the three consecutive final examinations. Table-1 below shows the groupings made on the basis of examination marks.

\section{Table-1-Shows the Grouping Made On Examination Marks}

\begin{tabular}{|c|c|c|c|c|c|c|c|c|}
\hline \multirow[t]{3}{*}{ Examination } & \multicolumn{8}{|c|}{ Academic Achievement } \\
\hline & \multicolumn{2}{|c|}{$1^{\text {st }}$ Division } & \multicolumn{2}{|c|}{$2^{\text {nd }}$ Division } & \multicolumn{2}{|c|}{$3^{\text {rd }}$ Division } & \multicolumn{2}{|c|}{ 'D' grade/fail } \\
\hline & $\mathbf{N}$ & $\%$ & $\mathbf{N}$ & $\%$ & $\mathbf{N}$ & $\%$ & $\mathbf{N}$ & $\%$ \\
\hline HSLC & 111 & 27.75 & 77 & 19.25 & 212 & 53 & ------- & --------- \\
\hline HS $1^{\text {ST }}$ YEAR & 15 & 3.75 & 112 & 28 & 112 & 28 & $161 *$ & $40.25 *$ \\
\hline HSSLC & 36 & 9 & 121 & 30.25 & 145 & 36.25 & 98 & 24.5 \\
\hline
\end{tabular}


*('D' According to the rules of Assam Higher Secondary Education Council, students who failed in one or two subjects, but passed in aggregate marks were awarded ' $\mathrm{D}$ ' grade in their $\mathrm{HS} 1^{\text {st }}$ year examination).

From the Table-1 it is revealed that students deteriorated in their Higher Secondary 1st year examination. It was found that out of $27.75 \% 1^{\text {st }}$ division holder in HSLC examination, only $3.75 \%$ students were able to secure first division in their HS $1^{\text {st }}$ year examination. $40.25 \%$ students got ' $\mathrm{D}$ ' grade and the percentage of students getting $2^{\text {nd }}$ division $3^{\text {rd }}$ division was equal(28\%).

It is also noticed in the table that the results of HSSLC examination was slightly better in comparison to the HS $1^{\text {st }}$ year examination. 9\% students secured first division. The percentages of students getting $2^{\text {nd }}$ and $3^{\text {rd }}$ division were $30.25 \%$ and $36.25 \%$ respectively.24.5\% students failed in their HSSLC examination.

The investigator further analyzed the marks obtained in the three aforesaid examinations and on the basis of the marks the achievements of students were categorized as follows-

a) Academic consistency

b) Academic improvement

c) Academic deterioration and

d) Academic fluctuation

In Table-2 different academic categories are shown made on the basis of student's achievement.

Table-2 shows the Academic categories of students:

\begin{tabular}{|c|c|c|c|c|}
\hline Category & Division & No of student & $\begin{array}{l}\text { Total no of } \\
\text { student }\end{array}$ & $\%$ of student \\
\hline $\begin{array}{l}\text { Academic } \\
\text { consistency }\end{array}$ & $\begin{array}{l}\text { I. } \\
\text { II. } \\
\text { III. }\end{array}$ & $\begin{array}{c}15 \\
24 \\
109\end{array}$ & 148 & 37 \\
\hline $\begin{array}{l}\text { Academic } \\
\text { Improvement }\end{array}$ & $\begin{array}{l}\text { II to I } \\
\text { III to II }\end{array}$ & $\begin{array}{c}6 \\
12 \\
\end{array}$ & 18 & 4.5 \\
\hline $\begin{array}{l}\text { Academic } \\
\text { Deterioration }\end{array}$ & $\begin{array}{c}\text { I to II } \\
\text { II to III } \\
\text { I to III } \\
\text { II to fail } \\
\text { III to fail } \\
\text { I to fail }\end{array}$ & $\begin{array}{c}55 \\
23 \\
13 \\
8 \\
85 \\
5\end{array}$ & 189 & 47.25 \\
\hline $\begin{array}{l}\text { Academic } \\
\text { Fluctuation }\end{array}$ & $\begin{array}{l}\text { I to II to I } \\
\text { I to III to I } \\
\text { I to III to II } \\
\text { II to III to II }\end{array}$ & $\begin{array}{c}14 \\
1 \\
15 \\
15\end{array}$ & 45 & 11.25 \\
\hline
\end{tabular}


From Table -2 it is observed that 37\% students have consistent academic records. Improvement in academic achievement occurred only in case of $4.5 \%$ students. Deterioration in academic progress was found in case of $47.25 \%$ students. $11.25 \%$ students had shown fluctuation in their academic progress.

\section{ADJUSTMENT LEVEL OF STUDENTS IN RELATION TO THEIR ACADEMIC PROGRESS}

Here an attempt has been made to find out the adjustment level of students categories on the basis of their academic progress. For the purpose an adjustment inventory, namely "Adjustment Inventory for School Student” was used. It contains questions divided in three areas- emotional, social, and educational. The scoring procedure for the instrument was in this type-if any answer indicative of adjustment ' $O$ ' is given, otherwise a score of ' 1 ' is awarded. The score of an individual in a given area on this instrument is the number of problems checked by the individual in that area. A high score therefore implies less adjustment.Table-3 shows the mean adjustment score of students under different academic categories.

Table-3 Mean adjustment score of students under different academic categories

\begin{tabular}{|c|c|c|c|}
\hline Category & $\mathbf{N}$ & $\mathbf{M}$ & SD \\
\hline Consistency & 148 & 14.48 & 6.40 \\
Improvement & 18 & 22.27 & 7.72 \\
Deterioration & 189 & 23.90 & 7.40 \\
Fluctuation & 45 & 20.22 & 5.18 \\
\hline
\end{tabular}

Table-3 reveals that mean score is highest in deterioration category(23.90) and the mean is found lowest in consistency category(14.48). As the high score indicate less adjustment therefore it can be said from the table that the student of 'deterioration category' has less adjustment and the 'consistency category’ signifies high adjustment.

\section{CONCLUSION}

In view of the foregoing discussions, the following conclusions appear tenable:

1. The academic achievement of students is not enthusiastic. A high percentage (47.25) of students is found in deterioration and a very low percentage (4.5\%) of students shows improvement in their academic achievement.

2. In comparison to the Higher Secondary First Year Examination, the achievement of students was better in their Higher Secondary School Leaving Certificate Examination.

3. The achievement of students in Higher Secondary School Leaving Certificate Examination found lower in comparison to their High School Leaving Certificate Examination.

4. Students belongs to the category of 'academic consistency' are better adjusted than the students belongs to the category of 'academic fluctuation.

5. Students under the category of 'academic deterioration' are less adjusted than the students of 'academic improvement' category. 
It is revealed by the study that most of the students deteriorated in their Higher Secondary First year examination. This is due to the fact that students may not be able to adjust him normally in the new situation of higher secondary level, which may interfere with their academic works and may lead to poor performance. In case of Higher Secondary School Leaving Examination also they have shown lower performance in comparison to their High School Leaving Certificate Examination's performance. The study also revealed significant relationship between adjustment and academic achievement of students. Parikh (1978), Swain and Panda (1982) and Panda (1997) also reported that adjustment and achievement are closely related. It can therefore, be said that a student cannot achieve well without proper adjustment.

\section{REFERENCE}

Ahluwalia,S.P. and Kalia, A (1987) "Adjustment Differences Among High Achieving Low Achieving Adolescents". Journal of Educational Research and Extension. 23(3)

Centi, P (1962) "Personality Factors elated to College Success, journal of Educational Research $55(4)$

Chawla, T.R. (1970)” Adjustment and Academic Achievement”. Psychological Studies 15 (1)

Choudhury,D. (2004) “A Study of Psycho-Social Problems Encountered by Students at +2 stage and Its Impact on Their Academic Achievement” Unpublished Ph. D. Thesis. Gauhati University, Assam.

Crow ,L .D. and Crow, A. (1956) Adolescent Development and Adjustment .Mc-grow Hill Book Company, New York $2^{\text {nd }}$ edition

Panda, B .N.(1997) "Impact of Creativity and Adjustment on Academic Achievement”. The Educational Review VC III (11)

Parikh. B. A. (1978) School Achievement in relation to Sex, Social adjustment and Family adjustment. Indian Psychological Review

Patel, A.S. and Joshi, R. G. (1997) “A study of Adjustment process of High and Low achievers”. Journal of Psychological Research, 21(3)

Sharma, R. R. (1983) Self-concept and Adjustment as factors in Academic Achievement. Indian Educational Review 18(1-8)

Sinha, A .K.P and Singh, R. P.(1993) Manual for Adjustment Inventory for School Students (AISS). National Psychological Corporation, Agra

Swain, K.S. and Panda, K. S. (1982)" Adjustment differences among adolescent boys and girls at different levels of Academic Achievement”. Journal of Education Research and Extension

Symonds, P. H. (1946) The Dynamics of Human Adjustment, New York, Appleton Century 